\title{
Hemel en hel
}

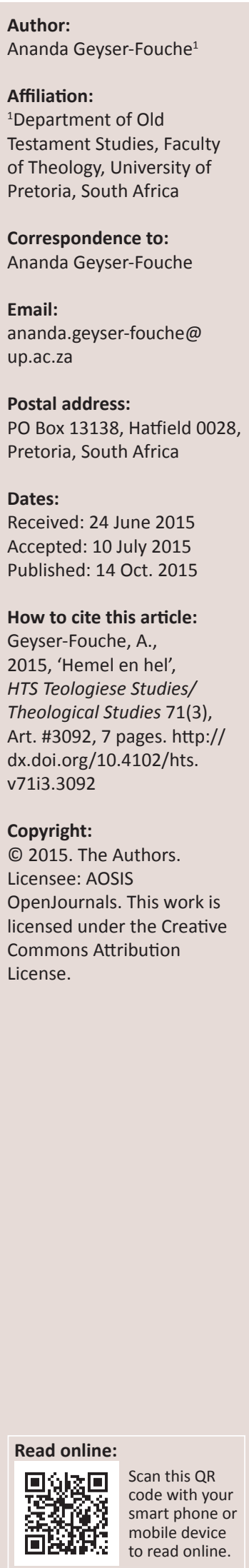

Heaven and hell. Any conversation on 'heaven and hell' is nothing else but a conversation about 'life after death'. To understand the concept of heaven, earth and hell as described in the biblical context and surrounding cultures, it is important to understand their concept of the cosmos and creation. Different perspectives of the universe lead to different ideas about life after death. Apocalyptic thoughts brought new perspectives to the understanding of life after death. All these different views can only be understood within the context in which they developed. Due to scientific results, the perception of the cosmos changed, urging us today to interpret ancient models metaphorically.

\section{Inleiding}

'n Gesprek oor 'hemel en hel' is eintlik niks anders as 'n gesprek oor die lewe na die dood nie. Ellens (2013b - my vertaling uit Engels) stel dit soos volg:

Ons is almal wesens wat geseën is met ' $n$ bewussyn van ons eie bewussyn. Daarom het ons die vermoë om te besin oor ons eie hoop en vrese, drome en verbeelding, ons persoonlike intuïsies en afbeeldings asof dit van buite af na ons toe kom. So het ons 'n goeie rede om te glo dat net buite die bereik van ons empiriese soeke, skyn daar 'n wêreld van die werklikheid te lê, wat ons slegs kan betree deur die fenomenologiese en heuristiese weet van die private innerlike self. Wat ons daar gewaar, blyk waarheid buite die data te wees, betekenis buite die empiriese bewyse, en voorkennis wat ervaring vooruitloop ... Aan die een kant, sal die meeste mense geredelik erken dat ons grondige kennis van die ewige wêreld anderkant ons alledaagse bereik en die huidige begrip, beperk is. Aan die ander kant weet ons almal dat as hierdie wêreld van die ondersoek afgesluit is vir ons, sal ons hele bestaan afgebreek word tot op die punt van byna betekenisloosheid. Mense word van nature gedring om na te dink, te ondersoek en te reflekteer aangaande ons onstuitbare verbeelding oor ons ewige hoop. (bl. 187)

Hierdie soeke het deur alle tye oor alle kulture heen gebeur en dit het ook gepaard gegaan met konteks, kennis, ervaring en verwysingsraamwerke. Elke kultuurgroep en/of volk het hulle eie simboliese universum gehad waarvolgens hulle geglo het. Hierdie simboliese universum hang ten nouste met 'n groep se wêreldbeeld en/ of idee van die heelal saam. ${ }^{1}$ Daarom is dit nodig om eers stil te staan by die ontwikkeling van die mens se idee van die heelal.

\section{Wêreldbeeld}

Tradisioneel verwys die meeste Hebreeuse tekste na die she'ol as die onderwêreld waarheen gestorwenes gaan. Die gedagte ontstaan uit hulle wêreldbeeld, naamlik dat die aarde plat is en op pilare staan. ${ }^{2}$ Onder die aarde is dan die she'ol en bokant die aarde is die hemel. Eers in die boek Daniël en die apokriewe boek Henog $^{3}$ word die moontlikheid genoem dat die mens se gees opwaarts kan keer na die dood (Collins 2004:522).

Die Ou Testamentiese tekste se beskrywing van die aarde spruit uit die skeppingsverhaal. Volgens Genesis 1:6-7 het die lug die boonste en die onderste waters van mekaar geskei. Die onderste waters was beperk tot een plek en is 'seë' genoem (v. 10). Die waters aan die bokant word beskryf as 'n hemelse oseaan wat bokant die lug is en daarom bokant die son, maan en sterre. Die rāqîă (uitspansel) is 'n koperkoepel, so hard soos 'n gegote spieël (Job 37:18) wat tussenin geplaas is om die boonste en die onderste water uitmekaar te hou (Gen 1:7; vgl. Johnston 2008:191).

1.Kyk onder andere na Collins (1986:7; 1998), Hanson (1979:443), Hengel (1974), Körtner (1988:55-56) en Nürnberger (2012) in die verband.

2.Kyk na Bernstein (1993) vir 'n volledige bespreking oor hoe die konsep hel in antieke kulture verstaan is. Kyk onder andere na die 2.Kyk na Bernstein (1993) vir' $n$ volledige bespreking oor hoe die konsep hel in antieke kulture verstaan is. Kyk onder andere na die
volgende: bespreking oor sheol (10;172); hoe sheol onderskei word van Ge-Hinnom (167-168; 172); vurig (146; 242); plek waarna God volgende: bespreking oor sheol (10; 172); hoe sheol onderskei word van Ge-Hinnom (167-168; 172); vurig (146; 242); plek waarna God 159-160; 196; 198;207)'n put/kuil (141; 146; 163-164; 166-167); 'n plek wat weggesteek is van God (141; 142-144); 'n tombe (185; 186; 187); vertaal as 'Hades' in die LXX (139; 167-168; 239).

3.Kyk ook na Tigchelaar (1999:47) se bespreking van die wêreldbeeld in sowel die Aramese as die Etiopiese 1 Henog 77:3. 
Lambert (1988:126) wys op die treffende ooreenkomste tussen mites van die Nabye Ooste, ten spyte van verskille in detail. Die idee dat daar in die begin net water bestaan het, kom voor in Homeros, antieke Egipte, die Babiloniese Enūma Eliš en ook in antieke Indië. Die skeiding tussen hemel en aarde as 'n primêre aksie van die skepping kom voor in die Orphics in Griekeland, die oudste Sumeriese mites asook die latere Mesopotamiese teks, in Genesis asook in antieke Indië. Ander konsepte wat in verskillende beskawings ooreenstem, is onder andere die idee dat gode op bergtoppe bly asook die konsep van 'n Pantheon wat as 'n familie uitgebeeld word (vgl. Lambert 1988:126). ${ }^{4}$

Funk (1996:75) verduidelik dat die wêreldbeeld in die Grieks-Romeinse tyd uit drie vlakke bestaan het: Die aarde was plat, in die vorm van 'n pannekoek (in Funk se woorde), met oorkoepelende hemele en vurige gedeeltes aan die onderkant. Die berge op die kante van die aarde was die pilare wat die lug opgehou het. Anderkant hierdie berge was aan die een kant die buitenste duisternis en aan die ander kant moontlik die Elisiese velde.

Dit verklaar die taal oor die hemel en die aarde wat in die Bybel voorkom, veral in die skeppingsverhaal. ${ }^{5}$ Volgens Genesis 1:1 was daar chaos voordat God dit georden het. Van Selms (1967:19) verwys in sy kommentaar op Genesis na God se skepping en sê dat die skepping tussen ewigheid en geskiedenis staan. Hy sê dat die skepping nie as geskiedenis beskryf kan word nie aangesien dit die voorloper (presedent) van die geskiedenis is. Skepping moes plaasvind voordat geskiedenis kon plaasvind. Voor God se skeppingswerk was daar chaos, wat nie van God gekom het nie. God het met sy skepping orde gebring. Met ander woorde, om te skep was om orde te bring, nie om van niks na iets te skep nie, maar om te orden.

Die wêreldbeeld van die antieke mens het finaal na Copernicus se ontdekkings ineengestort. Nicolaus Copernicus was 'n wiskundige en sterrekundige in die tyd van die Renaissance. Hy het ' $n$ heliosentriese model van die heelal geformuleer wat die son, eerder as die aarde, in die sentrum geplaas het (Cushing 1998:59). Dit lei tot 'n ineenstorting van die tradisionele siening dat die aarde plat is. Hierdie verandering in wêreldbeeld word verder uitgebrei deur die wetenskaplike ontdekkings van onder andere Galileo (Cushing 1998:74) en Newton (Cushing 1998:103).

Die ineenstorting van die simbolies universum in die Renaissance en die Verligting (Aufklärung) het daartoe gelei dat daar veral op die gebied van die astronomie, astrofisika, fisika en geologie ' $n$ totale nuwe begrip van die kosmos ontwerp is in vergelyking met die kosmos van die Bybelse tyd. Die kosmos en wêreldbeeld wat in die antieke tyd

4.Kyk na Lambert (1988) en Luttikhuizen (1999) vir'n bespreking van Ou-Testamentiese mitologieë binne die konteks van die Antieke Nabye Ooste asook Bernstein (1993:22, $33-39,88$ ) vir'n volledige bespreking oor die Griekse mitologie met betrekking tot die skepping en/of ontstaan van die kosmos.

5.Kyk in Dozeman, Römer en Schmid (2011) en Edenburg (2011) na die verskillende opinies oor watter mites in die Genesis-skeppingsverhaal ter sprake is. gegeld het, verskil drasties van wat die wetenskap duidelik gemaak het.

Die begrip hemel en aarde is dus iets wat in die geskiedenis gebore is en binne die begripsvermoë en wêreldbeeld van die antieke mens ontstaan het. Wat van groot belang is, is dat God nie 'n geskiedenis het nie. Hy was voor die geskiedenis en is die Skepper van orde. Daarom is dit moontlik om ten spyte van vandag se wêreldbeeld God nog steeds as die God van orde - teenoor chaos - te beskou.

Voortspruitend uit verskillende samelewings se konsep(te) van die heelal asook hulle mites oor die skepping ontstaan hulle sieninge van die lewe na die dood. In die volgende gedeelte sal (aan die hand van Ellens (2013b:187-204) die ontwikkeling van die konsep 'lewe na die dood' in verskillende kontekste kortliks bespreek word.

\section{Die ontwikkeling van mense se siening met betrekking tot die lewe na die dood oor tyd en kulture heen Egipte}

Die Egiptiese verstaan van die lewe na die dood is deur hulle klimaat en geografie bepaal. Reeds 3000 jaar voor Jesus, Philo en Josephus het die Egiptenaars 'n vasgestelde idee gehad van wat die lewe na die dood behels. Die Egiptiese konsep van die lewe na die dood is 'n refleksie op die ritme van die Nylrivier se jaarlikse vloed wat aan die land die herlewing van die nimmereindigende sikliese lewe van veld en vee gebring het. Dit is ook gereflekteer in die daaglikse dood en opstanding van die son. Die onstuitbare herhaling van lewe na die daaglikse en seisoenale dood het vir die Egiptenaars die simbool van die veerkrag van hoop geword. Hulle het 'n verwagting gehad oor die volhoubaarheid van die menslike persoonlikheid ten spyte van die dood van die liggaam. Die liggame van afgestorwenes is gepreserveer om 'n verbinding te bewerkstelling tussen die verheerlikte persoon en die mens wat op aarde gelewe het. Morele gedrag is ook aan die finale staat van die lewe na die dood verbind. Dit het aanleiding gegee tot heelwat poëtiese liedere en gedigte, soortgelyk aan die wat in die Hebreeuse Psalms gevind word. Die konsep van 'n oordeel oor die siel van die mens het die waarde van die sterflike lewe en mens op aarde bekragtig. Hierdie Egiptiese verstaan van die lewe na die dood is tot in die Middeleeue sterk gehandhaaf toe die Westerse beskawing omvangryke invloede teweeg gebring het (Ellens 2013b:190).

\section{Die vrugbare halfmaan}

In teenstelling met die Egiptenaars het die inwoners van Kanaän (Palestina) en Mesopotamië 'n negatiewer voorstelling van die lewe na die dood, en veral van die onderwêreld (doderyk of Sheol), gehad. Die Gilgamesj-epos ${ }^{6}$ is waarskynlik een van die bekendste tekste oor die lewe na die dood en beklemtoon die donker en skaduagtige beeld

6.Kyk na De Villiers (2006) vir'n bespreking hieroor. 
van die dood. Sowel Kanaänitiese as Israelitiese idees en konsepte oor die lewe na die dood het karaktertrekke van dieselfde model oor die onderwêreld (Ellens 2013b:191).

In Israelitiese literatuur word na die lewe na die dood verwys as die Sheol (meestal in Afrikaans vertaal as doderyk). Een van die interessantste aspekte van die lewe na die dood in hierdie gebied was die idee van hemelvaarte of hemelbesoeke. Dit kom ook meer gereeld in die Hebreeuse tekste van die Tweede-tempel Judaïsme voor (vgl. Collins 1998). Dit het die debat geopen oor die moontlikheid om God te sien, terwyl Exodus 33 spesifiek waarsku dat niemand God kan sien en kan lewe nie.

Die Kanaänitiese literatuur uit Ugarit vertel van ontmoetings tussen God en menslike helde. Alhoewel die Hebreeuse Bybel baie krities staan teenoor die meeste mitologiese vertolkings van onsterflikheid, het baie van die mitiese simbole wel in die literatuur neerslag gevind (vgl. Ellens 2013b:191-192).

In die tydperk van die eerste tempel bied die Hebreeuse literatuur min konkrete verwysings na óf 'n aangename óf 'n onaangename lewe na die dood. Sheol was die ongedifferensieerde antieke Griekse en Mesopotamiese onderwêreld. Alhoewel daar oor die algemeen oor 'n lewe na die dood geswyg is, is dit tog interessant dat die raadpleeg van dooies sterk afgekeur word (Ellens 2013b:191-192).

Dit is belangrik om daarop te let dat, ongeag die mate waartoe Sheol deur die Hebreeuse Bybel beïnvloed is, dit as deel van God se domein beskou is - dit is veral duidelik uit die boek Job asook uit Psalms wat hoop dat God die mens nie daar sal laat verrot nie. Dwarsdeur die Ou-Testamentiese literatuur is daar 'n unieke idee wat optimisties is en dit is die idee van God se spesiale ooreenkoms (verbond) met die mens. Dit is ook die verbond van genade en skep die hoop dat dit nie vir die mens moontlik is om hom- of haarself uit God se omarming te sondig nie. Dit lei dan ook uiteindelik daartoe dat die Judaïsme asook die Christelike geloof baie sterker klem lê op 'n hoopvolle lewe na die dood eerder as 'n troostelose einde.

In die tydperk van die tweede tempel is meer kreatiewe idees rondom 'n salige lewe na die dood ondersoek. Hierdie tydperk word ook gekenmerk as die tydperk waarin apokaliptiese denke en bewegings hoogty gevier het. Tydens die Babiloniese ballingskap, onder invloed van die antieke Iranse ideologie en hulle teologie van Zoroastrianisme, het die konsep van dualisme sterk in die Hebreeuse denke na vore gekom. Die kosmiese konflik tussen die koninkryk van lig teenoor die koninkryk van duisternis is net so aan die Zoroastrianisme ontleen (Ellens 2013b:193).

\section{Griekeland}

In die Griekse mites oor die lewe na die dood is die mees aangrypende gedeelte die van Demeter se rou oor die verlies van sy dogter (Persephone), hoe hy haar aanmoedig om te ontsnap van haar ontvoerder, die Griekse god Hades, en hoe sy herstel word tot 'n opgewekte lewe. Uit die Griekse denke is vele aspekte oor die lewe na die dood ondersoek, onder andere verskeie idees oor die siel, positiewe en negatiewe bestemmings in die lewe na die dood, die moontlikheid van opwekking asook die potensiële afwesigheid van enige onsterflikheid. Die denke is ook oorlaai met konsepte soos hemelreise. Soos wat Platoniese rasionele idealisme gedurende die ontstaan van die Christendom en die Rabbiniese Judaïsme die oorheersende konsep in die Mediterreense wêreld geword het, het teologieë van die transendente wêreld meer ineengevleg geraak in Westerse ideologieë sodat die hemele die toppunt van redding in die Romeinse wêreld geword het.

\section{Die Judaïsme}

Die Tweede-tempel Judaïsme was meer ontvanklik vir idees van omringende kulture. Ellens (2013b) stel dit so:

While in exile in Babylon the Jews were mystified by the question of how and why God could allow his chosen people to be abused and embondaged by pagan powers. (bl. 194)

Hierdeur het die Judaïsme 'n gerieflike antwoord in die Zoroastrianisme gevind waarvolgens daar 'n voortdurende kosmiese konflik tussen goed en sleg, God en die duiwel, was. Die Israeliete is egter weggevoer in ballingskap omdat hulle aan die verkeerde kant van daardie oorlog gekom het. Die Ou-Testamentiese profete het dit beweer en die volk se ervaring het dit bewys. Vanaf die boek Daniël tot met die opkoms van die Rabbynse Judaïsme het idees soos 'n hemelse koninkryk, transendente reise van die siel, opwekking uit die dood en onsterflikheid toenemend vanaf Kanaänitiese, Babiloniese, Persiese, Zoroastrianisme, Griekse en Romeinse bronne in verskeie vorme van Joodse en Christelike denke na vore gekom (Ellens 2013b:194-195).

\section{Tekste met apokaliptiese perspektiewe}

Oor die geskiedenis van hemel en aarde, of hemel en hel, het navorsing net die getuienis van tekste wat in verkillende kulture, elk met verskillende wêreldbeelde, ontstaan het. Die tekste wat meestal verwys na hemel, hel; en lewe na die dood is hoofsaaklik tekste wat as apokaliptiese tekste of dan tekste met apokaliptiese perspektiewe bekend staan. Dit is redelike laat tekste en het 'n unieke ontstaansgeskiedenis en verloop gehad. Elkeen verteenwoordig 'n unieke perspektief van die tyd waarin dit ontwikkel het en die konteks wat daartoe gelei het (vgl. Collins 1998).

Die inherente uitgangspunt van apokaliptiese denke is die geloof in die eksistensie van 'n transendente wêreld waarvan daar net deur openbaring kennis kan wees. Barr (2006b) beskryf dit soos volg:

$[T]$ he world of the Apocalypse is mysterious and exotic, with lambs and dragons, beautiful women and beasts, heavenly messengers and human observers. There are wars and earthquakes, cosmic catastrophes and heavenly liturgies, and blood as high as the horses' bridles. It is a world in which we must learn to find our way around. (p. 72) 
Barr (2006b:74) verwys na die feit dat apokaliptiese literatuur nooit as ' $n$ eiesoortige genre bestaan het nie voordat dit in 1832 deur Friedrich Lücke opgemerk is nie. Vroeër het geleerdes dit gewoon gelykgestel aan profetiese literatuur wat voorspellings gemaak het oor werklike of spirituele gebeure wat in die geskiedenis of aan die einde van die tyd sou gebeur (vgl. Barr 2006b:74). Russell (1964) wys op twee definitiewe eienskappe wat hierdie tipe literatuur van profetiese literatuur onderskei. Eerstens is dit die feit dat die apokaliptiese literatuur pseudoniem is en dat dit gewoonlik in geskrewe literatuur gekonstrueer is, terwyl die klassieke profete hulle orakels meestal in toesprake gelewer het wat later neergeskryf is. In apokaliptiese literatuur kom daar ook baie meer simboliese en esoteriese elemente voor (vgl. Barr 2006b:74). Tweedens, soos by die profete bestaan die konsep van beloning en straf ook, maar die profete verwoord dit in terme van aardse gebeure terwyl die apokaliptiese literatuur dit in terme van kosmiese gebeure verwoord. Barr (2006b:74) noem die vyf kenmerke wat vandag redelik algemeen as tiperend van apokaliptiese literatuur aanvaar word:

1. Dit berus op die aanspraak dat 'n geheime openbaring aan 'n siener of 'n profeet gegee is.

2. Die openbaring vind plaas in 'n droom, 'n visioen of wanneer die siener op ' $n$ hemelse reis weggevoer word. Soms word al drie vorme gekombineer.

3. Die openbaring vind gewoonlik plaas deur 'n figuur soos 'n engel wat as mediator, gids en/of interpreteerder vir die siener optree.

4. Die openbaring is gewoonlik nie selfverklarend nie, maar bestaan uit ' $n$ verskeidenheid misterieuse simbole wat diere (soms dele van verskillende soorte diere met meer koppe), mitiese figure en getalle insluit.

5. Die ontvangs van die openbaring word soms aan 'n figuur uit die verlede toegeskryf (soos Jesaja, Sefanja, Henog, Daniël, Esra, Petrus, Moses).

Barr (2006b) definieer apokaliptiese literatuur soos volg:

An Apocalypse is a secret revelation given to some seer or prophet in a dream, a vision, or a transportation to heaven and mediated by some heavenly guide and interpreter, using a variety of arcane symbols and often attributed to some figure from the past. (bl. 75)

Tog is dit nie so eenvoudig om tekste te orden en te kategoriseer nie. Veral in die latere profete is daar duidelike tekens van apokaliptiese perspektiewe, maar in baie gevalle kan dit aan profetiese eskatologie toegeskryf word.

Profetiese en apokaliptiese tekste hanteer die geskiedenis verskillend. Die apokaliptiese skrywers stem met die profete ooreen wat glo dat God op 'n spesifieke stadium in die geskiedenis sal ingryp om die wêreld te oordeel. (Amos is ' $\mathrm{n}$ klassieke voorbeeld daarvan as hy praat van die 'dag

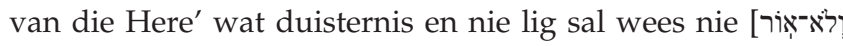

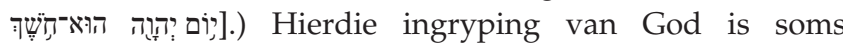
voorgestel as die 'einde', maar Amos verduidelik dat die

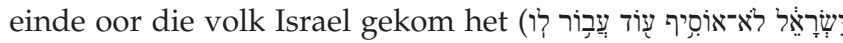

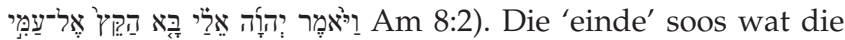

profete dit uitbeeld, is gewoonlik die 'einde' van Israel, Juda, Assirië of Babilonië. Hulle het dit nie verstaan as die einde van die wêreld nie. Soms is dit wel epies met kosmiese beelde beskryf (vgl. Jes 13:10:

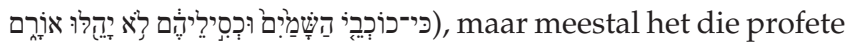
spesifieke historiese gebeure aangedui. God se oordeel is as die vernietiging van ' $n$ aardse mag, Israel, of die nasies beskou, terwyl sy redding as die herstel van Israel in hulle land beskou is (vgl. Collins 1997:5-6).

Die apokaliptiese skrywers gaan in vele opsigte verder as hulle profetiese voorgangers. In die histories-georiënteerde apokaliptiese literatuur word die geskiedenis in 'n sekere aantal periodes of tydperke verdeel. In hierdie tekste is daar 'n gevoel dat die geskiedenis 'n vaste tydsduur het en dat dit vooruit bereken kan word sodat 'n kosmologiese einde van die geskiedenis voorspel kan word. Die boek Daniël is die enigste Joodse apokaliptiese skrywe wat poog om die aantal dae te bereken totdat die 'einde' sou kom. Waarskynlik is die mees gewigtige verskil tussen apokaliptiese en profetiese eskatologie die finale eindpunt van die geskiedenis. Die eskatologie van die profete is radikaal deur 'n nuwe geloof in die oordeel van die dood en die moontlikheid van die beloning en straf van individue na die dood verander. 'n Fisieke opstanding is slegs een van die vorms wat 'lewe na die dood' kan aanneem. Collins (1997:6) sê dat van die apokaliptiese literatuur die doel van die lewe beskou as die moontlikheid om 'n engel te word. Die apokaliptiese skrywers se algemene bekoring met die hemelse engele-wêreld word duidelik uit hulle hoop op hierdie vorm van beloning. Die apokaliptiese literatuur gee indrukke van 'n hemelse engelewêreld in die hede, en diegene wat die hemelse reise beleef het, kleur dit verder in. Na die dood kan die regverdige hoop om vir ewig deel van hierdie hemelse wêreld te wees (vgl. Collins 1997:6-7).

Die apokaliptiese literatuur en apokaliptiese denke het dikwels in gevalle van onderdrukking as 'n krisisverskynsel ontstaan. Dit is 'n ideologiese uitvloeisel van 'n gemeenskap wat hulle lewensituasie so erg beleef dat dit tot 'n gevoel van sinneloosheid lei. So 'n gemeenskap skep dan 'n nuwe ideologie om die betekenisloosheid van hulle lewe mee te vul. Apokaliptiese denke dui op 'n radikale nuwe sienswyse en agting vir die geskiedenis. Daarvolgens het die geskiedenis 'n einde bereik en al wat oorbly, is dat die gelowiges hulleself voorberei en God se koninkryk afwag. Radikale pessimisme oor die sin van die geskiedenis versmelt met radikale optimisme dat die geskiedenis deur die koninkryk van God vervang gaan word (vgl. Gottwald 1985:585). Apokalips was dus nie net ' $n$ literatuurverskynsel nie, maar ook 'n sosiale fenomeen, gebore uit 'n krisis wat op 'n godsdienstige vlak aangespreek word. Dit lei tot apokaliptiese eskatologie wat wel raakpunte met profetiese eskatologie het, maar wat veral met betrekking tot straf en beloning radikaal van mekaar verskil. Die apokaliptiese skrywers was dus die enigstes wat 'n toekomspersepsie oor die lewe na die dood gehad het.

Vir hierdie studie is dit nie nodig om meer as 'n bondige blik op die apokaliptiese tekste van die Ou Testament te gee nie. In 
die Nuwe Testament is die boek Openbaring die boek met die sterkste apokaliptiese perspektiewe. Een van die bekendste tekste in die Nuwe Testament oor die lewe na die dood is die berig van Jesus se hemelvaart in Handelinge 1:1-11.

Wat betref die Ou- en Nuwe Testament is dit genoegsaam om die wêreldbeeld van 'n wêreld in drie vlakke, 'n ordelike skepping en die antieke mens se verstaan van die lewe na die dood aan te stip. Dit is steeds moontlik om ten spyte van vandag se wêreldbeeld God steeds as die God van orde teenoor chaos te beskou. Dit wil voorkom asof die raakpunt tussen die Ou- en Nuwe Testament met die verstaan van orde te make het. God het orde geskep en Hy gee hoop op elke mens se belewenis van chaos. God gee hoop vir die wat ly - vir die martelaar ${ }^{7}$.

Verskillende tekste van verskillende kulture en tye beeld verskillende persepsies van die lewe na die dood uit. Dit is egter nodig om ook te kyk wat oor die lewe na die dood in die belydenisskrifte staan. Van die belangrikste konsepte in die belydenisskrifte is die konsep van 'neergedaal na die hel' en die konsep van 'opgevaar na die hemel'.

\section{Belydenis: Descendit ad inferna}

Verskeie geleerdes ${ }^{8}$ het die neerdaling van Christus na die hel en die vertaling daarvan bestudeer, asook die moontlikheid dat die voorsetsel ad dalk eerder in moet wees. ${ }^{9}$ Die hele debat kom neer op die twee basiese denkrigtings wat onder die reformatore bestaan het. Die een siening, wat veral deur Calvyn gehandhaaf is, dui op Christus se lyding en angs aan die kruis, terwyl die ander siening neerkom op sy dood en verblyf in die graf (doderyk). Volgens die Heidelbergse Kategismus, Vraag 44, dui die neerdaal ook op die benoudheid, smart, verskrikking en helse kwelling waardeur Christus in sy ganse lyding maar veral aan die kruis gegaan het (Engelbrecht 1943:38).

Hierdie gedeelte kan dalk eerder verklaar word wanneer die woord inferna binne konteks verstaan word. Oberholzer (1961:91) wys daarop dat die term eerder verband hou met die Ou-Testamentiese begrip van die onderwêreld (doderyk/Sheol) en nie met die hel (gehenna) ${ }^{10}$ nie. Engelbrecht (1961) verduidelik die verskil soos volg:

Die woord 'hel' word in die Afrikaanse Vertaling deurgaans slegs gebruik om die Griekse woord ge'enna weer te gee, wat op sy beurt weer die Nuwe Testamentiese begrip vir eskatologiese strafoord vir die goddelose aandui, die plek waarin hulle 'met liggaam en siel' gewerp sal word Mat 5:30; 10:28; Opb. 20:13-15. (bl. 103)

\footnotetext{
7.Nogtans moet daar gewaak word teen "pie in the sky when you die'-teologie of voorspoedsteologie, asook teen' $n$ teologie van straf en vergelding of ' $n$ regverdiging vir onderdrukking. ('n Mens glo nie omdat jy verwag dat jy aan die einde van die tyd 'n prys daarvoor gaan kry nie, of nog erger, uit'n vrees vir die 'hel' nie. Geloof is nie op verdienste of vrees gegrond nie, maar op'n God met'n verbond van genade, uit wie se omhelsing die mens hom-/haarself nie kan sondig nie.)

8.Kyk onder andere na Engelbrecht (1961), Engelbrecht (1943), Gemser (1944), Oberholzer (1961) en Van Rensburg (1961).
}

9.Kyk ook na Buitendag (2009) se artikel in hierdie verband.

10.Kyk ook na Janse van Rensburg en Van Eck (2010) se bespreking in die verband.
Engelbrecht (1961) haal Gemser (1944) aan wat daarop wys dat die woord inferna deurgaans die Latynse vertaling vir die woord Sheol is en dat dit dus eerder op die doderyk of die onderwêreld dui:

Die Latynse Bybel het sorgvuldig die spraakgebruik van die oorspronklike Grieks gevolg. Dit vertaal hades met infernus en geёna met gehenna. As dus die belydenisartikel spreek van 'n neerdaal van Christus ad inferna of ad infernos, dan bedoel dit die hades van die Nuwe Testament, die 'doderyk', en [nie] die (nie) geëna, die 'hel' nie; as die laaste bedoel was, sou die geloofsartikel gelui het: descendit ad gehennam. (bl. 104)

Engelbrecht (1961) sluit af deur te sê dat dit nie 'n onbybelse gedagte is om te sê dat Christus se neerdaling na die hel die volgende betekenis het nie:

... [Hy het] inderdaad by sy nederdaling die verlossing aan die vromes in die doderyk bekend gemaak het en dat Hy hulle vrygemaak het om na die Paradys in die hemel te gaan. In die Nuwe Testament is die paradys immers nou in die 'derde hemel' (2 Kor 12:2-4). (bl. 112)

Van Rensburg (1961:99-101) wys ook op die ontwikkeling in die betekenis van Sheol teenoor gehenna, maar ondersteun die gedagte dat Christus se neerdaling verstaan moet word as dat dit ten doel gehad het om die vromes te red.

Nog 'n debat wat hieruit gevolg het, behels wanneer en hoe Christus na die hel neergedaal het. Het dit voor of na sy dood gebeur, na liggaam of na siel? (Buitendag 2009:6). Buitendag verwys na die onbegrensdheid van tyd buite liniêre denke. Die verstaan van die woord inferna as doderyk en Christus se neerdaal as verlossing van alle vromes ${ }^{11}$ onderskep tog ook op 'n manier hierdie hele debat.

\section{Opgevaar na die Hemel}

Oor die belydenis van Jesus se hemelvaart sê Van Aarde (2012) die volgende:

Ons belydenis oor Jesus se hemelvaart wil daarom nie ons aandag vestig op 'n geografiese konstellasie van hel onder en hemel bo die aarde nie. Dit is veel meer 'n belydenis van 'n gelowige worstelaar wat God se verhoging vanuit die diepste ellende aanvaar en glo dat God red. ... Die saak waaroor dit in ons belydenis oor Jesus se hemelvaart gaan, is ons troos dat ons in lewe en sterwe aan Jesus Christus behoort. In beeldspraak word ons oortuig dat Christus namens ons ons saak by God bepleit. (bl. 1)

Pienaar (2014) skryf soos volg oor hemelvaart:

Om die teologiese betekenis van hierdie gebeure te ontsluit, is nie so eenvoudig nie. Die rede is dat ons vandag 'n Copernicaanse kosmologie huldig, waarvolgens ons die aarde sien as 'n planeet wat saam met ander planete om die son in 'n elliptiese wentelbaan wentel, met net leë ruimtes tussenin sonder enige teken of vorm van lewe. Die mense van die Bybelse tyd en vir lank daarna het 'n mitiese wêreldbeeld gehuldig. Vir hulle was die kosmos soos 'n drielaagsjokoladekoek met die hemel daarbo, 
ons wêreld in die middel en die wêreld van die doderyk of die hel onder ons. (bl. 1)

\section{Gevolgtrekking}

Dat die mens nog altyd oor die lewe na die dood ${ }^{12}$ gewonder het en ook altyd daaroor sal wonder, is 'n voldonge feit. Net so is dit 'n voldonge feit dat die mens se persepsie, simboliek en metaforiese taal daaroor van geslag tot geslag en van kultuur tot kultuur verskil. Von Ehrenkrook (2013) som dit soos volg op:

It is no surprise, then, that speculations on the realm of death and the post-mortem condition have played a prominent role in religious literature since the dawn of human writing itself. And yet this common endeavor-spanning millennia across the globe- to resolve the uncertainty of death's specter, to cast a light on the darkness of the realm beyond, has yielded no certainty or clarity but a wild variety of possibilities, a multiplicity of heavens and hells, so to speak, that invariably mirror 'the values of the society that produced [them]'. (bl. 97)

Vir die mens wat ná Copernicus lewe, is dit dus nie moontlik om anders as metafories na die Bybel se beelde van hemel en hel te kyk nie. Alhoewel die skrywers van die tyd dit nie metafories bedoel het nie omdat dit vir hulle 'n werklike wêreldbeeld was, kan dit vandag net metafories verstaan word. Soos wat die mens nog altyd bewus was van die onvermoë om die lewe na die dood te verstaan en nog altyd maar net in simboliese en metaforiese taal daaroor kon praat, net so kan dit vandag nog nie anders verwoord word nie. Die lewe na die dood bly vir elke mens misterie, misterie wat saamhang met God se grootheid, sy soewereiniteit, sy alwetendheid en sy onbegryplike genade.

Binne die beperkinge van eie onvermoë, asook binne die beperkinge van taal en woordeskat, kan enige poging om iets te probeer verwoord van wat die outeur dink en/of voel die hemel is, nie logies, met rasionele beredenering gedoen word nie. Dit kan slegs in terme van 'n gevoel en bewussyn uitgedruk word, en dan die bewussyn van God se teenwoordigheid: Die hemel is wanneer die gevoel en bewussyn van onbekommerd wees, van vrede en van tevredenheid wat 'n mens ervaar, ewigheidswaarde kry. Dit is wanneer 'n mens stil word in God se teenwoordigheid (hetsy in gebed, in 'n gewyde kerkatmosfeer, in die natuur of waar ook al) ewigheidswaarde kry. Die hemel is dus wanneer die moment van ' $n$ transendente Godservaring nie meer momenteel is nie, maar ewig. Met ander woorde, dit is wanneer ' $n$ belewing en bewuswees van God se teenwoordigheid nie meer deur tyd en ruimte begrens word nie. In die mees eenvoudige metaforiese taal kan dit vergelyk word met die ervaring van ' $n$ versadigde kind op 'n moeder se skoot of 'n kleinkind wat in stilte by 'n oupa sit - vir altyd.

\section{Erkenning}

Hierdie artikel is 'n verwerking van 'n voordrag gelewer tydens 'n openbare gesprek in 2014 wat deur die Hervormde Teologiese Kollege (HTK) gereël is, met die vraag: Wat is die 12.Kyk ook na Segal (2004) en Van Aarde (2008) vir'n bespreking van hierdie tema. hemel en die hel? As hoof van die HTK het Dr Christo van der Merwe die gesprekke gefasiliteer en daarom het ek dit goed gedink om hierdie artikel vir sy huldigingsbundel aan te bied.

\section{Mededingende belange}

Die outeur verklaar hiermee dat sy geen finansiële of persoonlike verbintenis het met enige party wat haar nadelig of voordelig kon beïnvloed het in die skryf van hierdie artikel nie.

\section{Literatuurverwysings}

Barr, D.L., 2006a (ed.), The reality of apocalypse: Rhetoric and politics in the book of Revelation, Society of Biblical Literature, Atlanta, GA.

Barr, D.L., 2006b, 'Beyond genre: The expectations of apocalypse', in D.L. Barr (ed.), The reality of apocalypse: Rhetoric and politics in the book of Revelation, pp. 7190, Society of Biblical Literature, Atlanta,GA.

Bernstein, A.E., 1993, The formation of hell, death and retribution in the ancient and early Christian worlds, UCL Press, London.

Buitendag, J., 2009, 'Descendit ad [in] inferna: "A matter of no small moment in bringing about redemption"', HTS Teologiese/Theological Studies 65(1), Art. \#273, 8 pages. http://dx.doi.org/10.4102/hts.v65i1.273

Collins, A.Y., 1986, 'Introduction: Early Christian apocalypticism', Semeia 36, 1-12. Collins, J.J., 1997, Apocalypticism in the Dead Sea Scrolls, Routledge, New York, NY.

Collins, J.J., 1998, The apocalyptic imagination: An introduction to Jewish apocalyptic literature, Eerdmans, Grand Rapids, MI.

Collins, J.J., 2004, Introduction to the Hebrew Bible, Fortress Press, Minneapolis, MN.

Cushing, J.T., 1998, Concepts in physics: The historical relation between philosophy and scientific theories, Cambridge University Press, Cambridge.

De Villiers, G., 2006, 'The Epic of Gilgamesh and the Old Testament: Parallels beyond the deluge', Old Testament Essays 19(1), 26-34.

Dozeman, T., Römer, T. \& Schmid, K., 2011, Pentateuch, Hexateuch, or Enneateuch?: Identifying literary works in Genesis through Kings, SBL, Atlanta, GA.

Edenburg, C., 2011, 'From Eden to Babylon: Reading Genesis 2-4 as a paradigmatic narrative', in T. Dozeman, T. Römer \& K. Schmid (eds.), Pentateuch, Hexateuch, or Enneateuch?: Identifying literary works in Genesis through Kings, pp. 155-168, $\mathrm{SBL}$, Atlanta, GA.

Ellens, J.H., 2013a, Heaven, hell, and the afterlife eternity in Judaism, Christianity, and Islam, vols. 1-3, Praeger, Santa Barbara, CA.

Ellens, J.H., 2013b, 'Excursus: Commemoration of Alan F. Segal: A critical digest of his "Life after death: A history of the afterlife in Western religions"', in J.H. Ellens (ed.), Heaven, hell, and the afterlife eternity in Judaism, Christianity, and Islam, vol. 3 , pp. 187-204, Praeger, Santa Barbara, CA.

Engelbrecht, J.J., 1961, “'Neergedaal na die Hel”: 'n Histories-dogmatiese deviasie', Hervormde Teologiese Studies 17(II/III/IV), 102-112.

Engelbrecht, S.P., 1943, 'Die nederdaling van Christus na die hel uit'n dogmenhistoriese oogpunt besien', Hervormde Teologiese Studies 1, 32-41.

Funk, R.W., 1996, Honest to Jesus: Jesus for a new millennium, HarperCollins Publisher, New York, NY.

Gemser, B., 1944, 'Die belydenis van Christus "neerdaling ter helle" in die lig van die gegewens van die Ou Testament', Hervormde Teologiese Studies 1(2), 65-73.

Gottwald, N.K., 1985, The Hebrew Bible: A socio-literary introduction, Fortress, Philadelphia, PA.

Hanson, P.D., 1979, The dawn of apocalyptic: The history and sociological roots of Jewish apocalyptic eschatology, Fortress, Philadelphia, PA.

Hengel, M., 1974, Judaism and Hellenism: Studies in their encounter in Palestine during the early Hellenistic period, SCM, London.

Janse van Rensburg, H. \& Van Eck, E., 2010, "'What's on the other side?" The resurrection revived: A critical enquiry', HTS Teologiese Studies/Theological Studies 66(1), Art. \#868, 10 pages. http://dx.doi.org/10.4102/hts.v66i1.868

Johnston, G.H., 2008, 'Genesis 1 and ancient Egyptian creation myths', Bibliotheca Sacra 165, 178-194.

Körtner, U.H.J., 1998, Weltangst und Welteinde: Eine theologische Interpretation der Apokalyptik, Vandenhoeck \& Ruprecht, Göttingen.

Lambert, W.G., 1988, 'Old Testament mythology in its ancient Near Eastern context', in J.A. Emerton (ed.), Congress volume: Jerusalem, Papers read at the Congress of the International Organization for the Study of the Old Testament, held 24-29 August 1986 at the Hebrew University of Jerusalem, Israel, pp. 124-143, Brill, August 1986 at the Hebrew University of Jerus

Luttikhuizen, G.P., 1999, Paradise interpreted: Representations of Biblical paradise in Judaism and Christianity, Brill, Leiden.

Nürnberger, K., 2012, 'Die einde van die wêreld: Die uitdaging van die moderne natuurwetenskappe aan die tradisionele eskatologie', HTS Teologiese Studies/ natuurwetenskappe aan die tradisionele eskatologie, HTS Teologiese Studies/
Theological Studies 68(1), Art. \#1254, 10 pages. http://dx.doi.org/10.4102/hts .v68i1.1254 
Oberholzer, J.P., 1961, 'Die Ou Testamentiese getuienis aangaande die nederdaling van Christus na die hel', HTS Teologiese Studies/Theological Studies 17(II/III/IV), 84-91.

Pienaar, K., 2014, 'Jesus se hemelvaart: Die kerk se wêreldvaart', Hervormer, Mei, bl. 1. Russell, D.S., 1964, The method and message of Jewish apocalyptic, 200B.C.-100A.D., Westminster, Philadelphia, PA.

Segal, A., 2004, Life after death: A history of the afterlife in the religions of the West, Doubleday, New York, NY.

Tigchelaar, E.J.C., 1999, 'Eden and paradise: The garden motif in some early Jewish texts (1 Enoch and other texts found at Qumran)', in G.P. Luttikhuizen (ed.), Paradise interpreted: Representations of Biblical paradise in Judaism and Christianity, pp. 37-62, Brill, Leiden.
Van Aarde, A.G., 2008, “'Op die aarde net soos in die hemel”: Matteus se eskatologie as die koninkryk van die hemel wat reeds begin kom het', HTS Teologiese Studies/ Theological Studies 64(1), 529-565. http://dx.doi.org/10.4102/hts.v64i1.30

Van Aarde, A.G., 2012, Die hemelvaart van Jesus en sy Koningskroon, Hervormer, Mei, bl. 1.

Van Rensburg, S.P.J.J., 1961, 'Die Nieu-Testamentiese getuienis aangaande die nederdaling van Christus na die hel', HTS Teologiese Studies/Theological Studies 17(II/III/IV), 91-102.

Van Selms, A., 1967, Genesis, Deel 1, Callenbach, Nijkerk.

Von Ehrenkrook, J., 2013, 'The afterlife in Philo and Josephus', in J.H. Ellens (ed.) Heaven, hell, and the afterlife eternity in Judaism, Christianity, and Islam, vol. 1 pp. 97-118, Praeger, Santa Barbara, CA. 